\title{
Women in German Politics: Still Jobs for the Boys?
}

Today most of the main political parties in Germany have some kind of mechanism designed to help increase the number of women in party structures and parliaments. In this article the author examines current levels of female representation in Germany's political institutions, both at federal and Land level. She outlines each party's policies regarding the advancement of women, examines their impact, and offers possible explanations as to why some party's good intentions are not matched by their records. A brief comparison of levels of female representation in political life in Eastern and Western Germany is also given. Overall the evidence suggests that in spite of a marked increase in the number of female politicians, men still dominate at the most senior levels, especially in the so-called people's parties.

Today women comprise over 52 per cent (i.e. the majority), of the German population. However this figure is not reflected in Germany’s political institutions, for example, only 32.3 per cent of members of the current Bundestag are female. Even so, this constitutes a new high for the Federal Republic, and is well above the average for European parliaments (17.6 per cent ${ }^{1}$ ) and the equivalent figure for the British House of Commons (18 per cent). However at the very top, men dominate, with many women close to the top in various institutions and bodies, but few actually reaching it. The choice of Angela Merkel as the leader of one of Germany’s largest parties, the Christian Democratic Union (CDU), in 2000 was a milestone, but this came about through exceptional circumstances, namely a corruption scandal of unprecedented proportions in the history of the Federal Republic. Furthermore, the male politicians who grudgingly accepted Merkel as the new leader were well aware that the holder of that post would not automatically become the party's chancellor candidate at the next federal election.

This article examines the stated aims of the main political parties with the reality of female representation and participation in German politics at federal and Land level. It then considers possible explanations for any discrepancies between the two. A comparison of the gender balance in political life in Eastern and Western Germany will also be made. The author argues that the increase in female participation in German politics since reunification has been more quantitative than qualitative, with most top jobs still in the hands of men. Furthermore, in spite of lofty aspirations and concrete measures to promote women, the political culture of the parties that dominate German politics is still essentially a masculine culture. 


\section{OVERVIEW}

Table 1 below shows the gender balance within the German federal parliament since reunification. While the trend is generally of a gradual increase in the proportion of female MPs across the board throughout the period, there are marked differences between the three parties of the centre and the more radical parties.

TABLE 1: WOMEN IN THE BUNDESTAG 1987-2003 ${ }^{2}$

\begin{tabular}{|l|l|l|l|l|l|l|}
\hline & CDU/CSU & SPD & FDP & GREENS & PDS & TOTAL \\
\hline $1987-90^{*}$ & $18(8 \%)$ & $31(16 \%)$ & $6(13 \%)$ & $25(57 \%)$ & - & $80(15 \%)$ \\
\hline $1990-94$ & $44(14 \%)$ & $65(27 \%)$ & $16(20 \%)$ & $3(38 \%)$ & $8(47 \%)$ & $136(21 \%)$ \\
\hline $1994-98$ & $41(14 \%)$ & $86(34 \%)$ & $8(17 \%)$ & $29(59 \%)$ & $13(43 \%)$ & $177(26 \%)$ \\
\hline $1998-2002$ & $45(18 \%)$ & $105(35 \%)$ & $9(20 \%)$ & $27(57 \%)$ & $21(60 \%)$ & $207(30.9 \%)$ \\
\hline $2002-$ & $56(23 \%)$ & $95(38 \%)$ & $10(21 \%)$ & $32(58 \%)$ & $2(100 \%)$ & $195(32.3 \%)$ \\
\hline
\end{tabular}

*West Germany only.

Sources: Europäische Datenbank. Frauen in Führungspositionen; Frauenbericht, 11. Parteitag der CDU Deutschlands, 7. November 1998, Bonn.

Under Germany's complex electoral system half of the MPs are elected in constituencies using the first-past-the-post system, the other half by PR from party lists. A closer look at the current Bundestag reveals that of the 195 female MPs elected in 2002, only 76, i.e. 39 per cent won constituency seats, the remaining 61 per cent being elected via party lists. In other words, three-quarters of all constituency seats were won by men. ${ }^{3}$

Other federal institutions contain far fewer women. Of the 69 members of the Bundesrat, currently only 12 are women, i.e. just 17 per cent. However, as is typical of German politics, among the deputy members the proportion of women is higher. (At present 28 from a total of 130 are women, i.e. 21.5 per cent). ${ }^{4}$ At government level the situation is much better. Of the 14 members of Gerhard Schröder's 
red-green cabinet, six are women, (i.e. 43 per cent). This is an improvement on the original line-up under the previous centre-right administration led by Helmut Kohl in which only three of the 18 members of the cabinet were women. But with the exception of the justice minister, the other five women all head what many would consider to be the 'softer' ministries. Including junior ministers, the current federal government has 17 female ministers (of 39), i.e. 43.5 per cent. ${ }^{5}$ The current president of the Bundestag is a man, although women have held this influential position in the past. As is the case in other political bodies, there are two female deputy presidents of the Bundestag, predictably from the left-of-centre parliamentary parties (Fraktionen).

For a variety of reasons it is often assumed that at 'lower' or more local levels of the political system a higher proportion of women are likely to hold political office than at national level. Possible explanations range from the practical, for example, less time spent away from home and the family, to the psychological, for example, that men may be more competitive by nature, and more goal-orientated in their career management (in the opinion of one female German $\mathrm{MP}^{6}$ ). However, if one calculates the proportion of seats in Land parliaments held by women, or counts the number of female ministers in the Land governments, the level of gender equality (or lack of it) is often worse than at federal level. This can be seen from table 2 below. Only one Land has a female Minister-President (SchleswigHolstein), and only five Land governments comprise over 30 per cent female ministers. Furthermore, as is the case at federal level, in most cases women run the 'softer' ministries, such as those concerned with social policy, the family, education, the environment, and of course, women's affairs. Obviously the political complexion of Land governments is a major factor, with more female ministers in left-ofcentre governments than right-of-centre governments, but the former are currently in the minority, which in turn affects the make up of the Bundesrat. The situation in Land parliaments is no better. Nine out of 16 currently have a lower proportion of female members than the Bundestag in Berlin.

In short, at Land level the German case does not provide much support for the hypothesis that it is easier for women to gain access to power structures lower down the hierarchy of decision making. Indeed it would appear to be easier to impose and fulfil quotas and other commitments at federal level where there is a large pool of female politicians to draw on than in the provinces. It is possible that we might find more women post-holders in local councils, but an analysis of post-holders at these levels is beyond the scope of this article. One possible explanation for the continued male domination of Land politics is linked to the fact that under German federalism, the Länder possess considerable power, 
therefore Land politics is taken seriously by men and is just as competitive as federal politics. In addition, success at Land level is the best springboard from which to launch a career in national politics. Every chancellor since Willy Brandt had previously been minister-president of one of the Länder.

TABLE 2: PERCENTAGES OF WOMEN IN PARLIAMENTS AND GOVERNMENTS AT LAND LEVEL

\begin{tabular}{|c|c|c|c|}
\hline Land & $\begin{array}{l}\text { Landtag } \\
(\%)\end{array}$ & $\begin{array}{l}\text { Land } \\
\text { Gov'ts } \\
\text { (\%) }\end{array}$ & Governing Parties \\
\hline Federal Level & 32.2 & 43.6 & SPD/Green \\
\hline Baden-Württemburg & 21.9 & 10.0 & CDU/FDP \\
\hline Bayern & 23.3 & 16.7 & $\mathrm{CSU}$ \\
\hline Berlin & 32.6 & 22.2 & SPD/PDS \\
\hline Brandenburg & 29.5 & 30.0 & SPD/CDU \\
\hline Bremen & 41.1 & 28.6 & SPD/CDU \\
\hline Hamburg & 28.9 & 4.5 & CDU/Schill/FDP \\
\hline Hesse & 30.9 & 30.0 & $\mathrm{CDU}$ \\
\hline Mecklenburg-Vorpommern & 32.4 & 27.3 & SPD/PDS \\
\hline Niedersachsen & 33.3 & 25.0 & CDU/FDP \\
\hline Nordrhein-Westfalen & 31.2 & 36.4 & SPD/Green \\
\hline Rheinland-Pfalz & 31.7 & 27.3 & SPD/FDP \\
\hline Saarland & 33.3 & 37.5 & $\mathrm{CDU}$ \\
\hline Sachsen & 33.3 & 10.0 & $\mathrm{CDU}$ \\
\hline Sachsen-Anhalt & 31.3 & 11.1 & CDU/FDP \\
\hline Schleswig-Holstein & 38 & 55.6 & SPD/Green \\
\hline Thüringen & 30.7 & 10.0 & $\mathrm{CDU}$ \\
\hline
\end{tabular}


As May 2003. Sources: Europäische Datenbank. Frauen in Führungspositionen; www.hessen.de/stk/; www.niedersachsen.de/

\section{PARTY POLICIES FOR THE ADVANCEMENT OF WOMEN}

Most of the main political parties now have established mechanisms aimed at increasing the numbers of women in positions of power. The primary device used is the Frauenquota, although the target level of female participation varies from party to party. Success rates vary too, as does commitment to the principles behind the quota. Several parties have also adopted the principles of 'gender mainstreaming'. However, as is the case in other European countries, practical considerations, such as the timing of meetings and the absence of childcare facilities at political gatherings, often render the quotas and good intentions meaningless for the would-be female politician. This article will now outline current policies on the advancement of women as practised by the main parties, to what extent they have been successful, and why (or why not).

\section{BÜNDNIS 90/DIE GRÜNEN: PIONEERS OF THE FRAUENQUOTA}

For some time the Alliance 90/The Greens have been at the top of the league in terms of the proportion of female Bundestag members. Indeed they were the originators of the Frauenquota in the 1980s to which other parties, especially their main electoral rival, the SPD, have had to respond. The aim of the Greens' Frauenquota is parity, hence on party lists for elections, men and women are placed alternately, with women occupying the first position and subsequent odd numbered slots, men the even ones (though women may also contest these). As table one showed there was a slight increase in the proportion of female Green MPs during the 1990s. ${ }^{7}$ The party is currently represented in 10 of the 16 Land parliaments and in every case bar one, the goal of parity has been reached. The Greens' record for being frauenfreundlich is reflected in the large number of senior posts held by women throughout party structures both at federal and Land level, for example, half of the members of the federal party executive are female, as are six of the ten members of the executive of the parliamentary party. ${ }^{8}$ At party conferences women who wish to speak are allowed to 'queue jump' if there are several men waiting to speak. The aim of parity has also led to the creation of many joint posts especially in the 
case of party speakers (the Greens' equivalent of chairs) and Fraktion leaders at federal and Land level. Currently there are two federal chairs, one male, one female, and two chairs of the parliamentary party in the Bundestag, both female at present.

The Federal Women's Council (Bundesfrauenrat) co-ordinates the Frauenpolitik of the federal party and the parliamentary party, and their equivalents at Land level, and organises an annual federal women's conference. In addition there are working parties at federal level on both Frauenpolitik and Lesbian politics. A mentoring scheme has operated since 2000 whereby older, more experienced, female politicians act as mentors for younger colleagues. While little information is available regarding the impact the scheme, it would appear to be an acknowledgement that quotas alone are not sufficient to guarantee women's access to positions of power. ${ }^{9}$ While quotas have made a quantitative difference to women in the party, it is hard to gage whether or not they have made a qualitative difference in terms of helping women reach the highest echelons of power because the Greens do not have very many ministers at federal or Land level. Two of the three Green ministers in the current government are male, and in spite of the Greens' disapproval of hierarchies and prima donnas, the party’s 2002 federal election focused on Joschka Fischer, the (male) foreign minister, who was their first ever 'chancellor candidate'. However, parity has been achieved elsewhere. Of the four Green ministers in Land governments, two are women, and one of Germany's two EU commissioners is a Green woman.

The quota is not uncontroversial and not without practical problems. Firstly, posts held by two individuals inevitably lead to confusion as to who has the ultimate authority to speak for the party. Then there are questions of principle and fairness since the quota amounts to positive discrimination. Quotas for 'new faces' who have not held a mandate before are sometimes enforced too, hence future prospects would appear to be quite bleak for experienced male politicians. Finally, while the quota stands at 50 per cent, only 36 per cent of Green party members are women. ${ }^{10}$ Marginally more women than men vote Green however. At the last federal election in 2002, 8.9 per cent of female voters voted Green, compared with 8.2 per cent of male voters, ${ }^{11}$ and in 1998 the respective figures were 8 per cent to 6 per cent. ${ }^{12}$ In addition, it could be argued that in terms of MPs, gender equality has been achieved, even surpassed, hence the quota is no longer necessary. On the other hand, some women fear that men would quickly take over if it were to be abolished. ${ }^{13}$ It is also worth noting that the 50 per cent quota was not fulfilled in terms of Green constituency candidates for the 2002 election, not that the party 
stands much of a chance of winning many of these. ${ }^{14}$ In short, while gender equality is a fundamental principle of Green thinking, putting it into practice can still be problematic and controversial.

It should not be forgotten that the Greens are technically a party with eastern and western origins since the merger with the East German civil rights campaigners of Alliance 90 and East German Greens after reunification. However the party has serious problems recruiting members and attracting voters in the east. Of approximately 46,000 members, less than 3,000 live in the five eastern Länder. ${ }^{15}$ The post-materialist Green message has not really taken root in the east where people were concerned with more basic economic and social problems in the immediate aftermath of reunification, and the relevance of Alliance 90 has inevitably diminished over the past 13 years. As a result the Greens have severe difficulties filling posts at all in the East, let alone fulfilling the Frauenquota. Apart from in Berlin, the party is not represented in any parliament in the five eastern Länder, and two Land branches lack a female speaker or co-speaker.

Overall the Greens have come closer to achieving gender equality than any other party, and did so well before the mainstream parties. In retrospect their contribution towards the feminisation of German politics has been considerable. However, the continuation of continued use of formal mechanisms to promote women suggests that they are aware that there is still no room for complacency.

\section{THE PDS: ROSA'S DAUGHTERS}

The federal election result of 2002 left the Party of Democratic Socialism (PDS) with only two Bundestag members, albeit both women, compared with a Fraktion of 37 members in the previous legislative period, 22 of whom were female (i.e. 61 per cent). As is evident from table one, the proportion of female PDS Bundestag members rose steadily during the 1990s. The party is also represented in six Land parliaments, and in all but one at least half of the PDS MPs are female. This high level of female representation has been achieved via a formal Frauenquota of 50 per cent, in line with the party's egalitarian ethos. As is the case with the Greens women are in theory placed in odd numbered slots on party lists, and if a man occupies the first place, women should be in second and third place. However, while 49 per cent of the party’s list candidates for the 2002 federal election were female, most constituency candidates were male, hence the overall percentage of female candidates was only 28 per cent. ${ }^{16}$ 
The PDS has a women's working party, LISA which campaigns to ensure that the 50 per cent quota is adhered to. LISA also aims to 'recognise, criticise, and work against patriarchal thought and behaviour within the PDS'. ${ }^{17}$ The implication is that such thought and behaviour does still exist within the party, hence formal quotas are still necessary to prevent male dominance.

At other levels in the party hierarchy the PDS's record on gender equality is reasonably good. In 2000 a woman, Gabi Zimmer, was chosen as the new federal chair of the party, and it appears that it was purely coincidental that the CDU had chosen a woman as its new chair shortly before. Currently over 50 per cent of the federal executive is female, and most of the party's executives at Land level comprise approximately 50 per cent women. There are five female Land party chairs/speakers, and three branches in the western Länder have two co-chairs, one male, one female. However only one of the six PDS Fraktionen at Land level is chaired by a woman. Two of the PDS's six ministers at Land level are female but this is too small a number to make assumptions regarding women's access to the highest political positions.

Superficially then the PDS has quite a good record of promoting women within its structures, at least in quantitative terms. However in qualitative terms the situation is rather different. For years the real power within the party lay in the hands of four men: the former federal chair, Lothar Bisky; the former Fraktion leader in the Bundestag, Gregor Gysi; the former chief whip, Dietmar Bartsch; and spindoctor and strategist, André Brie. Only Gysi and Bisky achieved nation-wide fame, and this has been a hard act for their successors to follow. For the 2002 federal election the party's campaign focused on a foursome, two men and two women, as opposed to one chancellor candidate like the other parties. However this may have had less to do with equality than with the fact that the PDS simply lacked a charismatic leadership figure following the resignation of Gregor Gysi a few months earlier. Gabi Zimmer, a provincial politician who was never a Bundestag MP, (once nicknamed 'Zonen-Gabi' by the press), has failed to become a household name.

While the public face of the PDS is fairly feminine and even youthful by the standards of German public life, the same cannot be said for its members who are predominantly elderly and 54 per cent male to 46 per cent female. ${ }^{18}$ In the western Länder three-quarters of PDS members are male. ${ }^{19}$ The party leadership is aware that the quota cannot always be filled, especially in the case of honorary positions, largely due to the demands of work and family life faced by eastern German women since reunification. ${ }^{20}$ The party also attracts slightly more male than female voters -4.3 per cent compared 
with 3.7 per cent at the last federal election in $2002 .^{21}$ Women are a key target group for the PDS, and issues such as affordable childcare and widows' pensions have featured prominently in the party's election campaigns. $^{22}$

Overall, the PDS has a relatively good record in terms of gender equality which is derived from its socialist/egalitarian platform, perhaps also helped by attitudes towards women in the workplace stemming from GDR times. Even so, women who have achieved high office, such as Petra Pau MP believe that the party has lost some of its earlier enthusiasm to promote women and has instead adapted to the norms of political life in the Federal Republic. In Pau's view, there is still a tendency for women to be more accepted in top jobs at regional level, than in the 'first division', i.e. at national level. ${ }^{23}$

\section{THE SPD: PARTY OF STELLVERTRETERINNEN}

Among SPD women there was obvious irritation when their conservative rival, the CDU, became the first major party to elect a female leader, especially because the SPD had been the more progressive of the two in terms of promoting women. In response, the chair of the SPD's women's organisation, the Working Group of Social Democratic Women (ASF), said this development within the CDU had nothing to do with women's politics but was simply born out of necessity. However, it could not be denied that the CDU had 'stolen the show' in terms of promoting women. ${ }^{24}$

The Social Democrats first introduced a women's quota in 1988, according to which, a third of posts and places on party lists should be occupied by women. This was partly a response to the Greens who were in ascendancy from the mid-1980s. The quota was raised to 40 per cent in 1994 . Although this is well short of parity, it could be argued that a higher quota cannot be justified since less than 30 per cent of the SPD's members are women. ${ }^{25}$ They are automatically members of the ASF. In spite of an increase in the number of female MPs in the Bundestag since the quota was introduced (see table 1), the quota of 40 per cent is yet to be reached in many areas of party life, and only 38 per cent of the current Bundestagsfraktion are female. For the 2002 federal election 37.5 per cent of the SPD’s constituency candidates were women, but only 34.5 per cent of those who won their seats were female. ${ }^{26}$ In contrast, 45 per cent of the party’s MPs elected via party lists are women, which suggests that it is still harder for female Social Democratic politicians to gain nominations for winnable constituencies than to get a favourable position on a Land list. The SPD is represented in every Land 
parliament, but only eight Fraktionen currently have over 40 per cent women MPs, with several others just below the 40per cent mark. The chair of the ASF has blamed this on insufficient observance of the party statute and variations in the selection systems used between regions. ${ }^{27}$ Since 1999 the SPD has adopted the concept and language of gender mainstreaming, which has been described as 'a qualitatively new phase in social democratic equality policy and in current endeavours towards party reform'. ${ }^{28}$ In 2001 a party commission was charged with the task of making gender mainstreaming one of the key principles on which the organisational development of the party should be based, but a year later ASF could not see any evidence of changes as a result of this. ${ }^{29}$

When it comes to political leadership, more than any other German party, the SPD is a party of Stellvertreterinnen (female deputies). The federal chair is the chancellor, Gerhard Schröder, and two of the five deputy chairs are female. Most of the 16 Land branches of the SPD have at least one female deputy chair, but only four of the 16 Land chairs are women. Even so, this compares favourably with the CDU's figure of just one female Land chair. The situation within the parliamentary parties in the Länder is similar. Again, in every Land there is at least one female deputy chair of the parliamentary party, (with 24 female deputy chairs in total, compared with 27 men), but all the chairs are men. However the quota has been reached in every Land party executive, and in the executives of both the party and the parliamentary party at federal level.

To have reached this level of female representation in the five eastern Länder is quite an achievement. Members are spread very thinly with only 6.5 per cent of all SPD members in the new Länder, ${ }^{30}$ although the proportion of female members is the same as in the West at just over 29 per cent. Even so, party workers admit that it is not always possible to fulfil the Frauenquota in every body or on every party list in the East. ${ }^{31}$

After 16 years in opposition, the election of the red-green coalition government in 1998 gave the SPD an opportunity to put its principles regarding equality into practice. As mentioned earlier, in the current cabinet, six of the 14 government ministers are women, and five of these are from the SPD. Generally their portfolios are predictable: health, education, development and women’s affairs, and the family. SPD women are also overrepresented in parliamentary committees that deal with these policy areas. $^{32}$ Including junior ministers, 38 per cent of the SPD’s federal ministers are female. The party is currently in coalition governments in seven of the 16 Länder and can boast the only female minister- 
president of a Land. In total the party has 48 ministers in Land governments (including junior ministers), of which 16 (i.e. 33 per cent), are women. ${ }^{33}$

As has been shown, the overall record of the SPD in increasing women's representation within party and government structures is mixed. The introduction of the women's quota has enabled a 'critical mass' of women to gain access to most structures and organisations of the SPD. However, the target figure of 40 per cent has not been achieved at every level. Women are still underrepresented in bodies associated with 'high politics' such as economics and foreign policy. Furthermore, with very few exceptions, in most bodies, the deputies are women but the chief is a man. Improvements in the direction of gender equality within the SPD in quantitative terms cannot top the Christian Democrats' coup by electing a woman as party chair. In the case of the SPD this post is unlikely to become vacant for the foreseeable future. On the positive side, however, the promotion of Frau Merkel inevitably revived the issue of gender politics with in the SPD. Women within the party have been discussing various options to help achieve their goals, including the possibility of a mentoring scheme similar to that of the Greens. They also recognise the need for a recruitment drive to attract more young women under 35. The ASF is also monitoring the impact of the new French electoral law, which requires party lists for second order elections to comprise an equal number of male and female candidates. Accepting that it would be virtually impossible to pass such a law in every German Land, the ASF has called on the SPD to adopt parity for party lists instead of the current 40 per cent goal. ${ }^{34}$ But at present the SPD still appears rather male dominated compared with its left of centre rivals, the Greens (especially in the West) and the PDS (in particular in the East).

\section{THE CDU: THE NEW WOMEN'S PARTY?}

As a centre-right party with links to the Catholic Church, the CDU would not be expected to have a good record in terms of gender equality. However, the CDU was conceived as a catch-all party, which aimed to appeal to all voters, including of course, women. The CDU has always enjoyed a high level of support among elderly women and housewives, especially churchgoers, indeed, at the 2002 federal election 44 percent of women over 60 voted for the CDU. ${ }^{35}$ However, the party's loyal female voters do not necessarily become members. At present only 23 per cent of CDU members are women. ${ }^{36}$ In recent years the party has modernised, partly due to the need to attract younger blood to guarantee its 
future, and in response to increased electoral competition since the 1980s. However, still essentially a typical European Christian Democratic party, the CDU often seems merely to pay lip service to progressive issues such as the environment, feminism, etc. Consequently few people would have predicted that it would be the first major party to elect a female federal chair. However, as mentioned earlier, the circumstances that brought Angela Merkel to power were highly unusual. Following revelations of political corruption, which demolished the reputation of former chancellor Kohl, a replacement was sought who had not been party to the 'Kohl system'. Of the limited choice of suitable candidates, Frau Merkel, formerly CDU general secretary, represented the greatest break with the recent past. In spite of Kohl's admiration for 'his girl' (seine Mädchen), as an easterner and a woman she was not part of the intimate circle around Herr Kohl, a factor that had tarnished the reputation of her rivals. The CDU has also scored other 'firsts' for women in German politics, including nominating a woman for the post of federal president in 1999, and producing the first female president of the Bundestag, Rita Süssmuth, a popular and progressive politician by Christian Democrat standards, who held the post from 1988 until 1998.

But should the CDU now be regarded as a female friendly party, and has having a female chair made any difference for other CDU women? On closer inspection it appears that the party still lags well behind other parties in this regard. Measures have been introduced to increase the proportion of female members of parliaments and other bodies, but the target level of female representation is lower than is the case with other parties.

From 1985 the CDU committed itself to equal opportunities within party structures but little progress was made for a decade. Then in 1996 the party adopted the 'quorum resolution' (Quorumbeschluss), which aimed to achieve female representation of at least a third of all elected posts and on party lists. The quorum resolution was originally adopted for a trial period of five years, but at the end of this period it was incorporated into the party statute. ${ }^{37}$ This development does appear to have had some impact, although in many forums the quorum is yet to be achieved. In the current Bundestag 23 per cent of CDU MPs are women. This is an improvement on the two preceding legislative periods, before the introduction of the quorum resolution, when the corresponding figures were just under 14 per cent. In particular, the quorum resolution appears to have increased the number of women on CDU party lists, and 35 of the party's 44 female MPs were elected in this way at the last federal election. However, the quorum was not applied to constituency seats. Only 20 per cent were contested by 
female candidates and only 12 per cent of the CDU's successful constituency candidates were women. This suggests that there is a lot of work to be done in the field of equal opportunities within the CDU. As is always the case with quotas, the quorum remains controversial within the party due to the potential to stigmatise those chosen to fulfil the quota. ${ }^{38}$ In a survey of female CDU MPs conducted during the previous legislative period less than half said the quorum resolution had had a positive effect on their political careers, but it was those who had already been MPs a long time who responded negatively. However, most respondents believed that the quorum resolution had heightened awareness of gender issues within the $\mathrm{CDU} .^{39}$ Also, at 33 per cent the quorum is way above the proportion of female party members, although there are wide variations between regions. In the new Länder, just over 30per cent of the members are female, but unlike in the old Länder where the figure has remained constant since reunification, the proportion of female members has dropped dramatically. ${ }^{40}$ Apart from the federal chair there are currently three other women in the 14 strong CDU presidium, and the total number of women in the federal executive is 16 (of 50), i.e. 32 per cent. ${ }^{41}$ However, at Land level only one of the 15 Christian Democrat chairs is female. As is the case with the SPD, in every Land branch of the CDU at least one of the deputy chairs is a woman, which could be interpreted as tokenism, i.e. the Quotenfrau. On Land party executives the picture is rather better, with seven of the fifteen with at least a third women members, and a further five with over 30per cent women. ${ }^{42}$ However, currently only one Fraktion at Land level contains at least a third women, in line with the quorum resolution, and only 15 of the CDU's 81 ministers at Land level are women (18.5 per cent).

The CDU has a women's organisation, the Frauenunion. According to Kolinsky, this was created 'to show emphatically the core place of women in and for the CDU ${ }^{43}$ This did not initially mean equality however. Even so, the Frauenunion cannot easily be sidelined since its chair is an ex officio member of the party executive and the organisation can contribute towards the formulation of party policy, for example, by initiating conference resolutions. ${ }^{44}$ The Frauenunion has also been described as a training ground for political leadership, ${ }^{45}$ although this was not the case with Angela Merkel, who is not regarded as strong advocate of women's politics.

There would appear to be several reasons why the quorum resolution has not been achieved in most forums and parliaments: firstly, because the it was non-binding until December 2001; secondly, because the kind of women who would be likely to push hard for equal opportunities for women would be more likely to find their political home in a left-of-centre party; thirdly, due to the practical 
problems faced by most female politicians with families. (Frau Merkel, born in 1954, does not have any children); finally, and perhaps most importantly, because the culture of a large, well-established party cannot be changed overnight, especially in the case of a party that is by nature conservative.

That this is still the case has become clear, since Merkel took over as CDU chair. Once her 'honeymoon period' had passed, both the media and her male rivals within the CDU and CSU became almost obsessed with the question of whether or not she was 'up to the job'. Her leadership qualities, and her power within the party and the Fraktion have been continuously questioned, fuelled by breaches of loyalty from within the CDU and CSU, most notably regarding the two parties' choice of chancellor candidate for the 2002 federal election. In the end the leader of the CSU, Edmund Stoiber, was chosen, but led the two parties to defeat. However, afterwards Merkel was re-elected chair of the CDU, and became chair of the CDU/CSU Fraktion in the Bundestag, thereby considerably strengthening her position.

Merkel's appearance too has been the focus of attention in a way that would be hard to imagine in the case of a male politician. However, she has shown her capacity for self-irony, for example, by permitting a highly unflattering photograph of herself to appear in an advert to attract a new PR company for the party, and by not objecting to an advertising poster, which was clearly mocking her hairstyle. ${ }^{46}$ Overall, however, it appears that many within the CDU and CSU still regard Merkel as 'ein Mädchen’ and not as a serious politician. Other prominent female CDU politicians also appear to have come under pressure from the party machine. Katarina Reiche's appointment as spokesperson for family affairs in 2002 was highly controversial because she was an unmarried mother. However, not long afterwards she announced that she intended to get married in church. ${ }^{47}$ Angela Merkel was also unmarried when she rose to prominence, but then suddenly married her partner of many years' standing.

\section{THE CSU: MEN WEAR THE LEDERHOSEN}

The CDU's Bavarian sister party, the CSU, is ideologically considerably more conservative than the CDU. The CSU does not operate any kind of women's quota and only 21 per cent of its Bundestag members are female. While 22per cent of all the party's Bundestag candidates were women, only 4per cent of its constituency candidates were. ${ }^{48}$ This impacts upon the overall figure for the joint CDU- 
CSU Fraktion and appears to be a source of irritation among the more progressive members of the CDU. ${ }^{49}$ Just 13per cent of CSU MPs in the Bavarian Land parliament are female, and 16.7 per cent of CSU ministers in the Land government. ${ }^{50}$ Like its sister party the CSU has a Women's Union, which pays particular attention to family policy. The organisation wants women to be more visible within the party, ${ }^{51}$ but makes few concrete demands to achieve this, apart from securing an agreement whereby women candidates would occupy two of the first five places on the party's Land list for the 2002 federal election. ${ }^{52}$

\section{THE FDP: WOMEN'S LIB-ERALS?}

The FDP, also known as 'The Liberals', might be expected to take a more progressive stance on gender equality than the right-of-centre parties. However the party's record is disappointing. There is no women's quota. Currently the FDP Fraktion in the Bundestag contains 37 men and 10 women, i.e. 22per cent, the same as the proportion of female candidates for the 2002 federal election. ${ }^{53}$ The proportion of female party members is slightly higher at 24 per cent. ${ }^{54}$ The party leadership at federal level is very male-dominated, with a male chair both of the party and the Fraktion in the Bundestag, and no female deputy chairs. In total, three of the 15 members of the party's presidium are female, as are nine of the 46 members of the federal party executive. ${ }^{55}$ During nearly three decades as part of the federal government the FDP from the late 1960s until the late 1990s very few FDP women rose to national prominence. The FDP is currently represented in nine Land parliaments, with an average of 21.4per cent of female MPs in each Fraktion. The party is junior coalition partner in five Land governments, with only one woman among its 15 Land ministers, while three of the 16 Land chairs are women. The Federal Union of Liberal Women was founded in 1990, and provides a forum for female party members to discuss issues of special interest to women, although it does not have the power to influence party policy directly. In 2002 the party executive was charged with the task of drawing up a strategy to make the FDP more feminine including the incorporation of the principles of gender mainstreaming and a commitment to increase the number of elected positions for women. ${ }^{56}$ However the Federal Union of Liberal Women rejects the notion of quotas, claiming they bring about quantitative improvements, but not qualitative changes, and lead to competition between women. 
Instead the organisation favours other methods to advance women including mentoring and the creation of networks with other women's organisations. ${ }^{57}$

Overall the case of the FDP appears to prove that progressive attitudes towards gender equality alone do not guarantee fair representation for women within the structures of a political party. The FDP is to a certain extent in the political wilderness at present - out of office at federal, out of many Land parliaments, and virtually non-existent in the new Länder. Furthermore, its monopoly of the role of 'kingmaker' with one of the two mass parties has been stolen, firstly by the Greens and more recently by the PDS in the East. Consequently a rethink of the party's profile and objectives is inevitable which might provide an opportunity for Liberal women to assert themselves in an effort to improve the party's miserable record in terms of promoting women.

\section{THE FAR RIGHT}

Three parties that can be categorised as right-wing extremist operate in the Federal Republic, namely the German People’s Union (DVU), the Republikaner, and The National Democratic Party (NPD). None has ever been represented in the Bundestag, but they do sometimes find success in Land elections. The DVU is currently represented in three Land parliaments. Two of its six MPs are female, as are two of its 16 Land chairs. ${ }^{58}$ The DVU's main rival, the Republikaner, is currently out of office at Land level. Four of the 33 members of its federal executive are women, as are three of its 16 Land chairs. ${ }^{59}$ The NPD is not represented in any land parliament and is more closely linked to Germany's violent right-wing extremist and neo-nazi scene than the other two parties. Another party which is not right-wing extremist in a traditional sense, but which shares similar policies on issues such as law and order, and is dominated by its charismatic leader, is the Schill Party. The party has experienced electoral success in Hamburg, where just 3 of its 25 Land MPs are women and none of its six ministers. ${ }^{60}$ As is typical of all far right-wing parties, all of those mentioned above take a very conservative and out-dated view of the role of women and do not seek to promote them within their own structures. It is also widely believed that these parties have little appeal to female voters. 
WOMEN IN POLITICS IN EASTERN GERMANY: FROM DOUBLE BURDEN TO DOUBLE QUOTA?

The former GDR was supposedly a state in which women enjoyed equality with men, primarily via full participation in the workforce. ${ }^{61}$ Cheap childcare facilities were provided by the state in order to facilitate this. However, behind the façade of sexually equality in the workplace lurked a more traditional domestic culture and the division of labour in the home was far from one of equality. Consequently women suffered under the so-called 'double burden' characteristic of state socialism. In political life too the notion of equal opportunities was clearly not taken too seriously. Although women were well represented in the lower levels of the ruling Socialist Unity Party (SED), real power lay entirely in the hands of men. No women entered the politburo, and one of the two 'candidate members’ was the highly unpopular wife of the former leader of the GDR, Erich Honecker. ${ }^{62}$

In spite of these severe shortcomings, East German women still had different experiences and expectations of public life to their West German counterparts. The question that now arises is to what extent the legacy of the GDR still influences women's attitudes towards participation in politics. Has that legacy made the political culture of the new Länder more conducive to women? How do levels of female representation in parliaments and other bodies compare with the West? Women are often labelled the 'losers of reunification', having lost facilities that were taken for granted in the GDR, such as cheap childcare and the right to abortion, and in many areas female unemployment is higher than male. Having lost out socially and economically since reunification, have eastern women lost out in terms of political power too?

In the case of parliamentary representation, women in the new Länder are slightly better represented than their western sisters, especially in the Bundestag (see table 3). However, in the higher echelons of power, this is not the case. Of the total number of ministers in Land governments, only 18.6 per cent are female in the new Länder, compared with 22.2 per cent in the old Länder. ${ }^{63}$

TABLE 3: EAST-WEST COMPARISONS

$$
\text { East }^{64} \quad \text { West }
$$


Female Bundestag

Members (per cent)

35.4

29.2

Female Members

of Land parliaments (per cent)

31.6

31.3

Female Ministers

in Land governments (per cent)

18.6

22.2

As May 2003. Source: Calculated from figures from the Europäische Datenbank. Frauen in Führungspositionen and from Kürschners Volkshandbuch Deutscher Bundestag, 15. Wahlperiode (Rheinbreitbach: NDV, 2003).

In short, when it comes to real power, there are still echoes of the old days of the GDR. On the political scene of the new Länder there are really only three real players, the CDU, SPD and PDS and only the latter has a good record of gender equality. In the previous legislative period (1998-2002), 38 per cent of Eastern German MPs were female and nearly a third of them were members of the PDS Fraktion. The demise of the PDS has affected the gender balance among eastern German MPs.

A controversial issue in federal politics is the so-called 'double quota' (Doppelquota). It has on occasion been suggested that an individual has been selected for a post as a token woman and token East German rolled into one, thereby fulfilling an unofficial 'double quota' ${ }^{65}$ In this way the dominant group in German politics, namely men from Western Germany need only surrender one post to fulfil the quotas, be they obligatory or out of good will. Such accusations have also been made in Land politics in the Federal Republic’s only 'east-west' Land, Berlin, which is in many ways a microcosm of reunited Germany. ${ }^{66}$

As mentioned earlier, both the CDU and the SPD are rather thin on the ground in the new Länder and this makes it hard to fill posts at all, let alone to fulfil the women's quota. This is less of a problem for the PDS with a total membership of around 78,000, as mentioned earlier, almost exclusively residing in the new Länder, nearly half of whom are female. ${ }^{67}$ 
Overall the evidence regarding women's opportunities in politics in the new Länder compared with the old Länder is mixed. During the first few years after reunification, when tension between eastern and western Germans was at its peak, it appeared that being an eastern woman in German politics was a double liability. More recently however, it might be an advantage, although the notion of the 'double quota' is not something the main parties would admit to. While being a woman from the East helped Angela Merkel represent a fresh start for the CDU when this was required, it does not necessarily count in her favour now. As is the case in the West, the likelihood of a woman gaining access to high office will usually depend on which party she joins. Even so, recent developments have produced potential role models to generate new interest in politics among women in the new Länder. However, according to one young female MP, future conflicts among politicians from the new Länder will not be between men and women but between generations, or more specifically, between the young who have grown up in reunited Germany and older generations that still identify with the former GDR. ${ }^{68}$

\section{CONCLUSION}

This article has provided a snapshot of the situation for women in German politics in 2003. Clearly there is scope for more detailed research into the factors that help or hinder female politicians in Germany, but some provisional conclusions can be drawn. Since reunification the proportion of female politicians has increased, both at Land and federal level. But although a 'critical mass' of women has been achieved at most levels, the improvement is more quantitative than qualitative. This is largely due to the fact that most parties' strategies to increase the number of female faces in their ranks have focused entirely on quotas for Land lists. Dissatisfied with the situation, a group of women formed a new women's party called Die Frauen in 1994. The party's aim is for 52 per cent of all German politicians to be female, in line with the make-up of the population. One method proposed is via party lists with 80 per cent female candidates to redress the fact that most constituency seats are held by men. Die Frauen polled only 36,000 votes at the 2002 federal election (0.1 per cent), an increase of 6,000 compared with $1998 .^{69}$

While the long-term significance of the election of a woman as chair of one of the 'big two' parties in the Federal Republic may not be great, this development did spark off renewed debate regarding the role of women in German politics. However, it would still appear that a woman's chance of achieving 
real political power is still not equal to a man's due to the culture of the two leading parties in German politics. The two parties that promote women, the Greens and the PDS, are unlikely to lead a government at federal or Land level in the near future. In addition, the old problem for women remains namely how to combine a political career with family life when there are so many evening and weekend engagements. This issue lies at the heart of the discrepancy between women who would like to take on positions of political leadership, and those who are actually able to do so, and goes back to the issue of political culture and working practices. In spite of quotas, by failing to address these issues, men, especially West German men, have managed quite successfully to hold on to political power in reunited Germany. In short, politics at the highest level in Germany still means 'jobs for the boys’.

\footnotetext{
${ }^{1}$ OSCE members, as March 2003. Source: Inter-Parliamentary Union (www.ipu.org).

${ }^{2}$ Shows the situation at the beginning of each legislative period. The male-female ratio tends to fluctuate during the course of a legislative period because MPs who leave parliament are replaced by the first unsuccessful candidate on the party list from the last election. For example, during the period 1998-2002 the number of women MPs rose to 211. From 2002, the Bundestag was reduced in size from 669 to 603 seats.

${ }^{3}$ Europäische Datenbank. Frauen in Führungspositionen. (www.db-decision.de/)

${ }^{4}$ Figures: www.bundesrat.de/

${ }^{5}$ Source: Europäische Datenbank. Frauen in Führungspositionen.

${ }^{6}$ Europäische Datenbank. Frauen in Führungspositionen. Interview with Petra Pau MP, January 2001. (www.dbdecision.de/Interviews/Deu/Pau_E.htm)

${ }^{7}$ The federal election of 1990 was an exceptional case when there were separate 5per cent thresholds for entry into the Bundestag in Eastern and Western Germany. The Western Greens failed to enter the Bundestag, hence the proportion of women MPs was unusually low.

${ }^{8}$ Source: Bündnis 90/Die Grünen website (www.gruene.de/)

${ }^{9}$ For a discussion see 'Drei Fragen zur Frauenpolitik - 15 Grüne Antworten', Schrägstrich 11-12/01, p.32

(www.gruene.de/frauenpolitik)

${ }^{10}$ As Dec. 2002. Source: www.pds-online.de/partei/daten/frauenanteil.htm

${ }^{11}$ Source: Bundeswahlleiter: www.destasis.de/presse/deutsch/wahl2002/p3001211.htm

12 www.aicgs.org/wahlen/elect98.htm

${ }^{13}$ Author’s interview with Monika Boeker, former Bundesfrauenreferentin for Bündnis 90/Die Grünen, Berlin, 4 August 2000.

Over 48 per cent of Green candidates on Land lists were women, but only 39 per cent of all Green candidates. Source:

Europäische Datenbank. Frauen in Führungspositionen. The Greens won one constituency seat at the 2002 Federal election, their first.

${ }^{15}$ As of Dec. 2001. Aktuell 2003 (Dortmund: Harenberg Lexikon Verlag, 2002), p.334.

16 Source: Europäische Datenbank. Frauen in Führungspositionen.

${ }^{17}$ www.lisa-frauen.de/wir/wir.htm. LISA stands for Linke Sozialistische Arbeitsgemeinschaft der Frauen in der PDS. (Left Wing Socialist Working Party of Women in the PDS).

${ }_{19}^{18}$ As Dec. 2002. Source: www.pds-online.de/partei/daten/frauenanteil.htm

19 Michael Chapra and Dietmar Wittich, Die Mitgliedschaft, der grosse Lümmel... Studie zur Mitgliederbefragung 2000 der PDS, May 2001, p.25.

20 'Auch die PDS hat Nachholbedarf bei der Beteiligung von Frauen. Parteivorsitzende Gabi Zimmer über Quotierungen, Hinterzimmerpolitik und Machtspiele’, Neues Deutschland, 20 Dec. 2001.

21

Source: Bundeswahlleiter: www.destasis.de/presse/deutsch/wahl2002/p3001211.htm

${ }^{22}$ The CDU's Speaker for Family Affairs, Katarina Reiche MP, believes many Eastern German women are attracted to the PDS due to its policies regarding childcare. Author’s interview Potsdam, 7 August 2000.

${ }^{23}$ Europäische Datenbank. Frauen in Führungspositionen.

Interview with Petra Pau MP, January 2001. (www.db-decision.de/Interviews/Deu/Pau_E.htm)

${ }^{24}$ Press release by Karin Junker MEP, chair of the Working Group of Social Democratic Women (ASF), 15 May 2000.

${ }^{25} 29.4$ per cent in December 2002. Source: www.pds-online.de/partei/daten/frauenanteil.htm

${ }^{26}$ ASF, Rechenschaftsbericht 2000-2002. (www.asf.spd.de/)

${ }^{27}$ Gleichstellungsbericht, SPD Parteitag, Dec. 1999, Introduction by Karin Junker MEP.

${ }^{28}$ www.spd.de

${ }^{29}$ ASF, Rechenschaftsbericht 2000-2002.

${ }^{30}$ As Dec. 2002. Source: www.spd.de.

${ }^{31}$ Author's interview with Petra Weis (SPD), Berlin, 3 Aug. 2000

${ }^{32}$ Gleichstellungsbericht, SPD Parteitag, Dec. 1999, Introduction by Karin Junker MEP.

${ }^{33}$ Figures: Europäische Datenbank. Frauen in Führungspositionen.
} 
34 ASF, Rechenschaftsbericht 2000-2002.

${ }^{35}$ Die Frauen haben gewählt - erste Analyse zum Wahlverhalten, Press Release, 26 Sept. 2002,

(www.frauenunion.de/fu_press/pr260902.htm)

36 Frauenbericht, 15 Parteitag der CDU Deutschlands, Frankfurt, 16-18 June 2002, p.3. (www.cdu.de/ptfrankfurt/berichte/berichte.htm)

37 Änderung des Satzungsrechtes. Beschlüsse des 14. Parteitages der CDU Deutschlands, Dec. 2001, Beschluss E1. (www.cdu.de)

${ }^{38}$ Author's interview with Katarina Reiche MP, (CDU), Potsdam, 7 August 2000.

${ }^{39}$ Frauenbericht, 13. Parteitag der CDU Deutschlands, 2000, p.17.

${ }^{40}$ As March 2002. In 1991 the proportion of women was almost 40per cent. Source: Frauenbericht 2002, p.10. (www.cdu.de)

${ }^{41}$ www.cdu.de/ueber-uns/

${ }^{42}$ As March 2002. Frauenbericht 2002, p.14.

${ }^{43}$ Eva Kolinsky, Women in Contemporary Germany. Life, Work and Politics (Providence/Oxford: Berg, 1993), p.239.

${ }^{44}$ Kolinsky, Women in Contemporary Germany, p.239.

${ }^{45}$ Kolinsky, Women in Contemporary Germany, p.249.

46 'Böse Miene zum guten Spiel', Spiegel Online, 2 January 2001.

47 'Mädchen mit Macht', Der Tagesspiegel, 4 July 2002; 'Stoibers Schaulaufen’, Der Tagesspiegel, 16 July 2002.

Europäische Datenbank. Frauen in Führungspositionen.

${ }^{49}$ Frauenbericht, 1998, p.7.

${ }^{50}$ Calculated from figures provided by the Europäische Datenbank. Frauen in Führungspositionen.

${ }^{51}$ Klausurtagung des Landesvorstandes der Frauen-Union der CSU (FU), 7-8 ${ }^{\text {th }}$ Feb. 2003. (www.csu.de/fu/)

52 www.csu.de/fu/

53 Europäische Datenbank. Frauen in Führungspositionen.

54

24.4 per cent in December 2002. Source: www.pds-online.de/partei/daten/frauenanteil.htm

55 Source: www.liberale.de/

${ }^{56}$ Beschluss des 53. Ord. Bundesparteitages der FDP, 10-12 ${ }^{\text {th }}$ May 2002. www.liberal-frauen.de

${ }^{57}$ Bundesvereinigung Liberale Frauen e.V, Grundsatzprogramm: ‘xx-xy ungelöst'. Arbeitspapier für eine progressive und

liberale Frauenpolitik. (www.liberal-frauen.de/)

58

www.rep.de

59 www.dvu.de

60 Source: Europäische Datenbank. Frauen in Führungspositionen.

${ }^{61}$ See Kolinsky, Women in Contemporary Germany, p.259-60.

${ }^{62}$ See Barbara Einhorn, 'German Democratic Republic. Emancipated Women or Hardworking Mothers?' in Superwomen and the Double Burden, ed. Chris Corrin (London: Scarlet Press, 1992), pp.144-46.

${ }^{63}$ Calculated from figures from the Europäische Datenbank. Frauen in Führungspositionen.

${ }^{64}$ Includes Berlin.

${ }^{65}$ Walter Zöller of the SPD confirmed that the 'double quota' does sometimes come into play, albeit unofficially. Author's interview, Berlin, 3 August 2000.

${ }^{66}$ Andreas Apelt of the Berlin CDU claimed that Easterners often only got positions if they satisfied the 'double quota' by being both eastern and female. 'Die großen Parteien tun sich in Berlin schwer mit der Herausforderung durch die PDS', Frankfurter Allgemeine Zeitung, 26 August 1997.

${ }^{67}$ www.pds-online.de

${ }^{68}$ Author's interview with Katarina Reiche MP, (CDU), Potsdam, 7 August 2000.

${ }^{69}$ See www.die-frauen.de/ Current membership figures are unavailable, but the party had 950 members in 1998 . Source:

Europäische Datenbank. Frauen in Führungspositionen. 